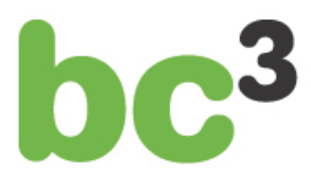

BASQUE CENTRE

FOR CLIMATE CHANGE

Klima Aldaketa Ikergai

\title{
The Slow Search for Solutions: Lessons from \\ Historical Energy Transitions by Sector and Service
}

\author{
Roger Fouquet
}

March 2010

BC3 WORKING PAPER SERIES

2010-05 
The Basque Centre for Climate Change (BC3) is a Research Centre based in the Basque Country, which aims at contributing to long-term research on the causes and consequences of Climate Change in order to foster the creation of knowledge in this multidisciplinary science.

The BC3 promotes a highly-qualified team of researchers with the primary objective of achieving excellence in research, training and dissemination. The Scientific Plan of BC3 is led by the Scientific Director, Prof. Anil Markandya.

The core research avenues are:

- $\quad$ Adaptation to and the impacts of climate change

- $\quad$ Measures to mitigate the amount of climate change experienced

- $\quad$ International Dimensions of Climate Policy

- $\quad$ Developing and supporting research that informs climate policy in the Basque Country

See www.bc3research.org for further details.

The BC3 Working Paper Series is available on the internet at http://www.bc3research.org/working_papers/view.html

Enquiries (Regarding the BC3 Working Paper Series):

Roger Fouquet

Email: roger.fouquet@bc3research.org

The opinions expressed in this working paper do not necessarily reflect the position of Basque Centre for Climate Change (BC3) as a whole.

Note: If printed, please remember to print on both sides. Also, perhaps try two pages on one side. 


\title{
The Slow Search for Solutions: Lessons from Historical Energy Transitions by Sector and Service
}

\author{
Roger Fouquet $^{12}$
}

This paper reviews past energy transitions by sector and service to identify features that may be useful for anticipating future transitions. As the United Kingdom was the first to make the transition from traditional energy sources to fossil fuel, its experiences may offer a unique perspective of relevance for a possible transition to a low carbon economy.

Although often considered a single event, the transition from traditional energy sources to fossil fuels was complex and involved numerous services and sectors at different times between 1500 and 1920.The main drivers for the energy transitions were the opportunity to produce cheaper or better energy services. In a majority of cases, the successful new energy source or technology provided the same service (i.e. heating, power, transport or light) with superior or additional characteristics (e.g. easier, cleaner or more flexible to use). The existence of a niche market willing to pay more for these characteristics enabled the new energy source and technology to be refined gradually until they could compete with the incumbent energy source. Nevertheless, this implied that, on average, the whole innovation chain took more than one hundred years and the diffusion phase nearly fifty years.

In the same way, since low-carbon energy sources and technologies are valued for their low climate impact, they will be able to develop gradually until they can compete with fossil fuels. However, for a transition to take place, low carbon energy sources and technologies will have to provide cheaper energy services - possibly helped by carbon taxes or tradable permit schemes. And, based on past experiences, $a$ complete transition to a low carbon economy is likely to be very slow.

Keywords: energy transition; low carbon economy; technological innovation

JEL Classification: N53, N54, O33, Q21, Q32, Q40, Q55, R41

Cite as: Fouquet, R. (2010) The Slow Search for Solutions: Lessons from Historical Energy Transitions by Sector and Service. BC3 Working Paper Series 2010-05. Basque Centre for Climate Change (BC3). Bilbao, Spain.

1 Basque Centre for Climate Change (BC3). Gran Via 35 - 2, 48009 Bilbao, Spain. Email: roger.fouquet@bc3research.org

${ }^{2}$ I am grateful for the helpful comments of Peter Pearson. 


\section{Introduction}

Ever since the transition from traditional energy sources to fossil fuels, human activity has been putting increasing pressure on the atmosphere's capacity to absorb and assimilate greenhouse gases. This new scarcity has created a demand for another major shift in energy sources - this time, towards less polluting ones (Pearce 2005). A possible future 'transition to a low carbon economy' depends on the substitution away from fossil fuels towards, for instance, new or renewable energy sources (Foxon et al 2008, Grubb et al 2008a).

The debate has focussed on targets for the achieving the transition. In particular, the UK Government seeks to reduce emissions by $80 \%$ by 2050 . Given this and other targets, the factors driving and the speed of an energy transition are of great interest.

Three main approaches exist to understanding energy transitions. First, a number of recent studies have looked directly at the possibility and nature of future energy transitions. For instance, Jefferson (2008) highlights the likely long lags between any attempts to create a shift and the completion of a transition to a low carbon economy. Edmonds et al (2008) and Grubb et al (2008b) stress the urgency of deploying new and renewable technologies, as well as increasing energy efficiency, to limit climate change. Gross (2004) and Jamasb et al (2008) show the important reductions in the price of renewable technologies needed to compete with the incumbent energy system. Modelling exercises suggest price incentives, such as a carbon tax, alone may have only limited success in achieving a shift and in reducing carbon dioxide emissions (Barker et al 2008). Inevitably, the government and other stakeholders have a central role to play in the diffusion of low carbon technologies (Foxon and Pearson 2007). The papers in Foxon et al (2008) also emphasize how firms in key sectors can be pivotal to a system change. Haas et al (2008) discuss the central role behaviour and the demand for energy services will play in driving any low carbon transition, the ambiguous effects of efficiency improvements on energy consumption and, thus, the need to understand services better.

Two less direct, but relevant, approaches look at past energy transitions. Second, a number of economists have examined (often with cross-section data) recent transition experiences in developing economies. The backdrop for many of these studies has been the severe constraints, as well as economic, social and environmental impacts, associated with using traditional energy sources. In households, for instance, the move up the 'energy ladder' (generally, from biomass to intermediate commercial fuels, such as coal or kerosene, to superior ones, such as natural gas, LPG or electricity) has often improved economic and social well-being (Pearson 1988, Leach 1992, Barnes and Floor 1996). Income, urbanisation, degree of electrification and access to running water, education, fuel prices and the 
opportunity cost of collecting traditional fuels are important drivers of the switch in energy sources (Heltberg 2004, Pachauri and Jiang 2008). Compared with the switches in the US, current developing economies appear to be experiencing energy transitions sooner (i.e. at lower levels of per capita income), faster and that involve a greater diversity of sources (Macrotullio and Schulz 2007).

Third, a number of historians and a few economists have looked further into the past to investigate the transitions that took place in current post-industrialised economies. These studies generally focus on a single country through time. Schurr and Netschert (1960) present the classic case study of energy transitions from biomass to coal to petroleum. The broad transition was much faster (i.e. decades instead of centuries) than for the United Kingdom (Stanislaw and Humphrey 1979, Fouquet and Pearson 1998, Warde 2007, Fouquet 2008). Other European experiences show that the historical context (for instance, resource availability, industrial and household energy service needs and government policies) is vital for explaining specific energy transitions (Gales et al 2007, Bartoletto and Rubio 2008, Madureira 2008, Kunnas and Myllyntaus 2009).

Because of the lack of detailed data, much of this historical literature has tended to analyse broad transitions within an economy. Often, however, different technologies are necessary to meet the needs of different sectors or services, and are part of a complex set of processes (Grübler et al 1999, Geels 2002, 2005). What is described as a single energy transition (say, from woodfuel to coal) is, in fact, a number of different transitions occurring, in some cases, in parallel and, in others, at very different times.

The purpose of this paper is to offer a more disaggregated perspective on historical energy transitions. Also, by examining a set of different transitions for the rich energy history of what is now the United Kingdom, it tries to draw some commonalities between them: the nature of the transitions, the speed of the transition (from innovation to competition with the incumbent technology to dominance) and the factors driving them.

Another reason to focus on the United Kingdom's past is that it was the first economy to make the transition to fossil fuels. To complete the transition, it needed to develop and diffuse new energy technologies. Other countries followed using those existing and tested energy technologies. Similarly, there is no precedent for the transition to a (widely applicable) low carbon economy. At present, the global economy needs to develop and diffuse new energy technologies. Thus, the history of the United Kingdom offers the only clear case of a first mover in a major energy transition.

In the next section, a brief definition of energy transition will be made. Then, the main historical energy substitutions and transitions in the United Kingdom will be presented for the four main energy services - heat, power, transport and light. Afterwards, fourteen different cases are compared to help 
understand the nature, speed and drivers of energy transitions. The following section offers some lessons for a transition to a low carbon economy. The final section concludes.

\section{Definition of Energy Transitions}

Before examining past transitions in detail, it might help to provide a definition of an energy transition. Van den Bergh and Oosterhuis (2005) talk about minor, intermediate and major energy transitions. The latter includes the invention of fire, the development of agriculture and the Industrial Revolution. Intermediate ones include the adoption of electricity and the shift from horse to car. For them, an example of a minor transition is the shift from coal to gas in heating the twentieth century.

So, a 'major energy transition' can be defined as a radical transformation of the economy and even the creation of new types of civilization. Interestingly, it makes a direct connection between the nature of the civilization and energy, as Cipolla (1962) did.

The 'intermediate energy transition' can be seen as the switch from one 'energy system' (or structure) to another. An 'energy system’ describes a particular production, distribution and consumption of energy - here, discussed at the scale of an economy. It is open to debate what constitutes a different energy system, but it is clear that, in many cases, parts of different systems coexist (or coexisted), as will be discussed later. This type of energy transition can be expected to lead to important transformations in the economy. Partly as a consequence, energy consumption is likely to change significantly.

Grübler (2008) characterises energy transitions as occurring when there are changes in the level, mix and/or quality of energy consumption. In addition to the change in energy source, important (i.e. major or intermediate) energy transitions are often associated with changes in the way an energy service is provided, which generally involves new technology. Here, for a 'minor energy transition', the term 'energy substitution' will be used, to indicate no important changes in the level of energy consumed or the quality of the service to the consumer.

\section{Historical Energy Transitions in the United Kingdom}

\subsection{Heating}

The need for heating has been one of the main drivers for energy consumption throughout history. A central problem associated with heating and the substitution between fuels has been the fuel's effect 
upon the product being prepared. In particular, coal was considered inappropriate for many industrial activities where the fuel came into contact with the product. The history of coal use has been a process of controlling and externalising its by-products from combustion. Once this problem was satisfactorily solved coal could be used for heating.

In households, the substitution took several hundred years. In sixteenth century England, with the introduction of chimneys and suitable grates, consumers in urban areas were starting to switch from woodfuels to coal (see Figure 1). By the seventeenth century, the cost of heating with coal was substantial cheaper than with woodfuels and residential coal consumption spread. By the beginning of the nineteenth century, coal accounted for more than four-fifths of domestic heating requirements (Fouquet 2008 p.76). Thus, the transition process took more than two hundred years.

\section{Figure 1. Share of Energy Consumption for Domestic and Industrial Heating in the United Kingdom (1500-2000)}

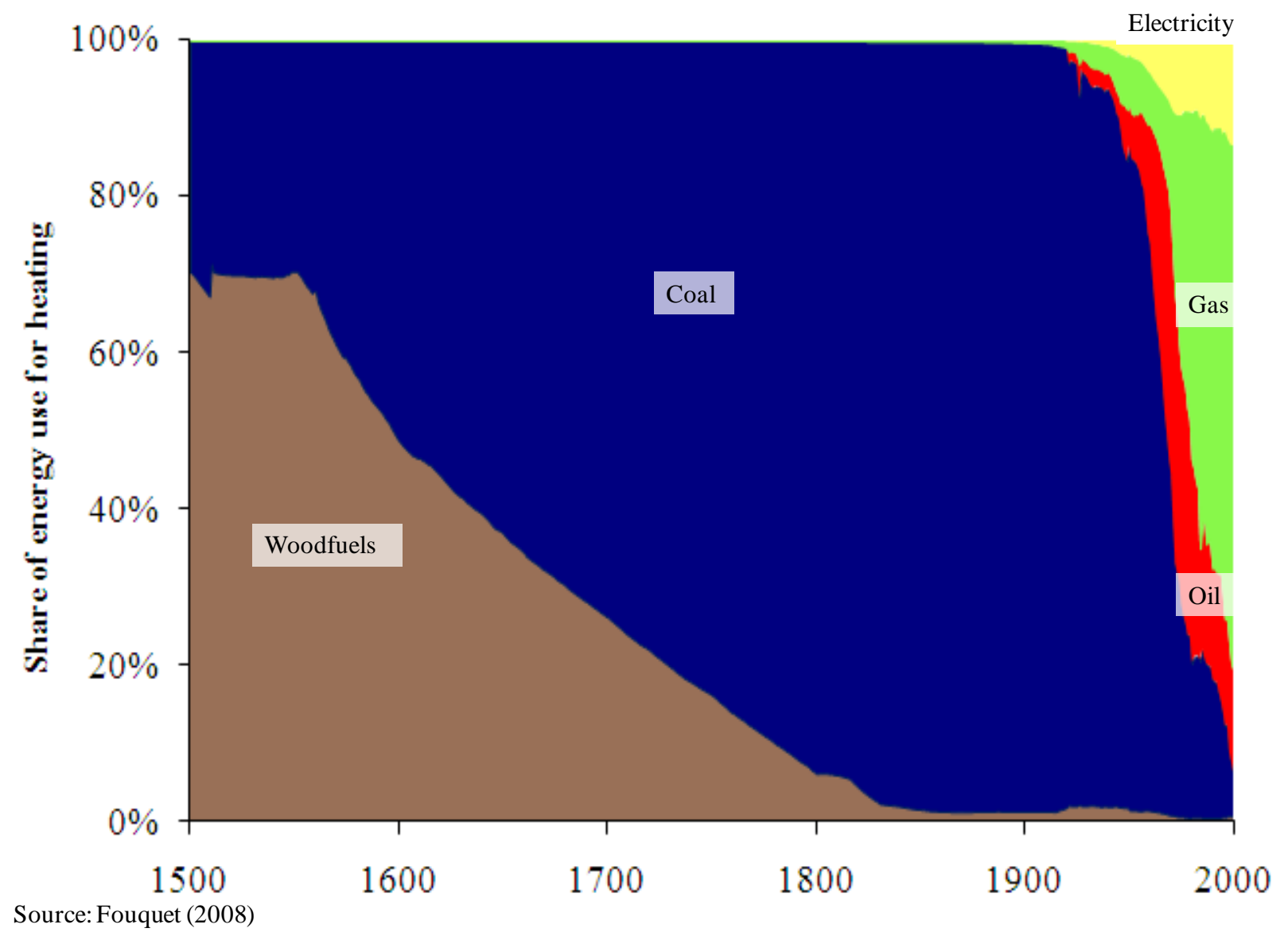


The iron industry was slowest to switch away from woodfuels. In the smelting process, the fuel came directly into contact with the iron ore and contaminated it. Thus, it took centuries of search to find a solution. In 1709, Abraham Darby offered a method involving coke, a purified form of coal. But, because coke smelting was so inefficient at first, it took nearly 50 years, and substantial improvements in the process, before the method was adopted. By the 1790s, coke iron production soared, and charcoal iron smelting started to disappear (King 2005).

In manufacturing more generally, the process of switch from woodfuel to coal took roughly 150 years (between the mid-sixteenth century to the end of the seventeenth century). Given the many subsectors involved, with different technological requirements and institutional structures for the dissemination of information, knowledge and skills, and in light of the slow `innovation chain` amongst households and in the iron industry, the transition was relatively rapid. In parallel, each industry searched and found solutions, and then adopted coal as its main energy source.

A more recent energy switch was the adoption of gas for heating buildings. From around the 1880s, gas (derived from coal) began to be used for heating. With improving technical efficiency of gas heaters, its use grew. Yet, by 1939, it only met 18 percent of the market. It was not until the 1970s, after the discovery of natural gas fields in the North Sea, that the price fell (making gas-heating cheaper than coal) and most households switched to gas and started installing central-heating (Fouquet 2008 p.85).

\subsection{Power}

Human labour was an inefficient way of converting calorific energy into power and throughout history has been complemented by more efficient animals (Smil 1994). For generating power, the horse provided greater and better directed force than its colleague, the ox. The introduction of the horseshoe in the ninth century enabled horses to be used more widely across Europe. But, it was not until the Norman invasion in 1066 that horses began to be adopted as a source of power in Britain - twenty years after the invasion, one-fifth of the animals available for power supply were horses (Langdon 1986). Between the end of the eleventh and the beginning of the fourteenth century, the horse population grew, sharing evenly the power requirements with oxen - regional dominance was reflected by the animal most suited for the local soil. By 1600, with the improvement in horse management, they became the main source of animalrelated power services (Langdon 1986), and the largest source of power until the ascendancy of the steam engine in the second-half of the nineteenth century (Fouquet 2008 p.125).

Alongside animals, water and wind mills offered a greater and more concentrated form of energy. Also, they were not at the mercy of fluctuations in the price of agricultural products. While water mills existed in Roman Britain, they received a boost of new ideas (e.g. catching water from above harnessed 
more of the water's power) between the seventh and tenth century. By the end of the eleventh century, mills had spread across Britain, mostly to crush grain for bread. This reduced the need for animals (and labourers) which did this task on a smaller scale. The windmill, which applied the concept of the watermill to a sail, was first introduced in the twelfth century, and diffused rapidly on the wave of economic growth of the thirteenth century (Langdon 2005).

Where geographical conditions were favourable and a sufficient market for its products existed, mills offered cheap power. And, the power was supplied in an increasingly concentrated form, enabling large tasks or many identical chores in close proximity. This helped intensify the production process, first for grain and then in the textile industry. Ultimately, though, they were limited to areas with strong rivers or steady winds. Despite technological developments and growth in total output until the end of the nineteenth century, mills could never rival animals or the steam engine for power services (Fouquet 2008 p.125).

Until the eighteenth century, power sources were either decentralised or geographically constrained. At first, in the eighteenth century, the use of steam engines was also constrained - to locations with very cheap fuel, and this meant a coal mine. For decades, the steam engine offered a cheap way of extracting water from mines and reducing the costs of producing coal. Because of its extensive use for this purpose, it benefited from economies of scale in production and major improvements in its fuel efficiency. As fuel efficiency improved, the steam engine became less geographically constrained, and started to be used in particular tasks in the textile industry during the first-half of the nineteenth century (Kanefsky 1979).

Given that watermills were located on rivers, and steam engines were built elsewhere, they did not replace mills. Rather, steam engines expanded in place of animals or labourers (see Figure 2). Given that they replaced animals and humans, they also offered a greater and more concentrated form of power, intensifying the production process. But, they were not as constrained and, from the mid-nineteenth century, steam power spread to other industries, replacing other forms of power and improving its efficiency. It became the dominant source of power and, consequently, coal replaced fodder as the main energy source for power services (Fouquet 2008 p.127). However, as Figure 2 shows, the inefficiency of human and horse power implied that, until the twentieth century, less energy was required for steam power than for animals.

In the twentieth century, electricity rose to dominance as the next power provider. Electricity benefitted from more than one hundred years of exploration and experimentation before Michael Faraday developed the electric motor in 1821. Like mills and steam engines, it also helped transform the 
production process. Workers using powered tools and equipment were no longer dependent on the rhythm of the steam engine or the mill. This increased the flexibility of the worker, who could start and stop equipment independently (Devine 1983).

Figure 2. Share of Energy Consumption for Power in the United Kingdom (1800-2008)

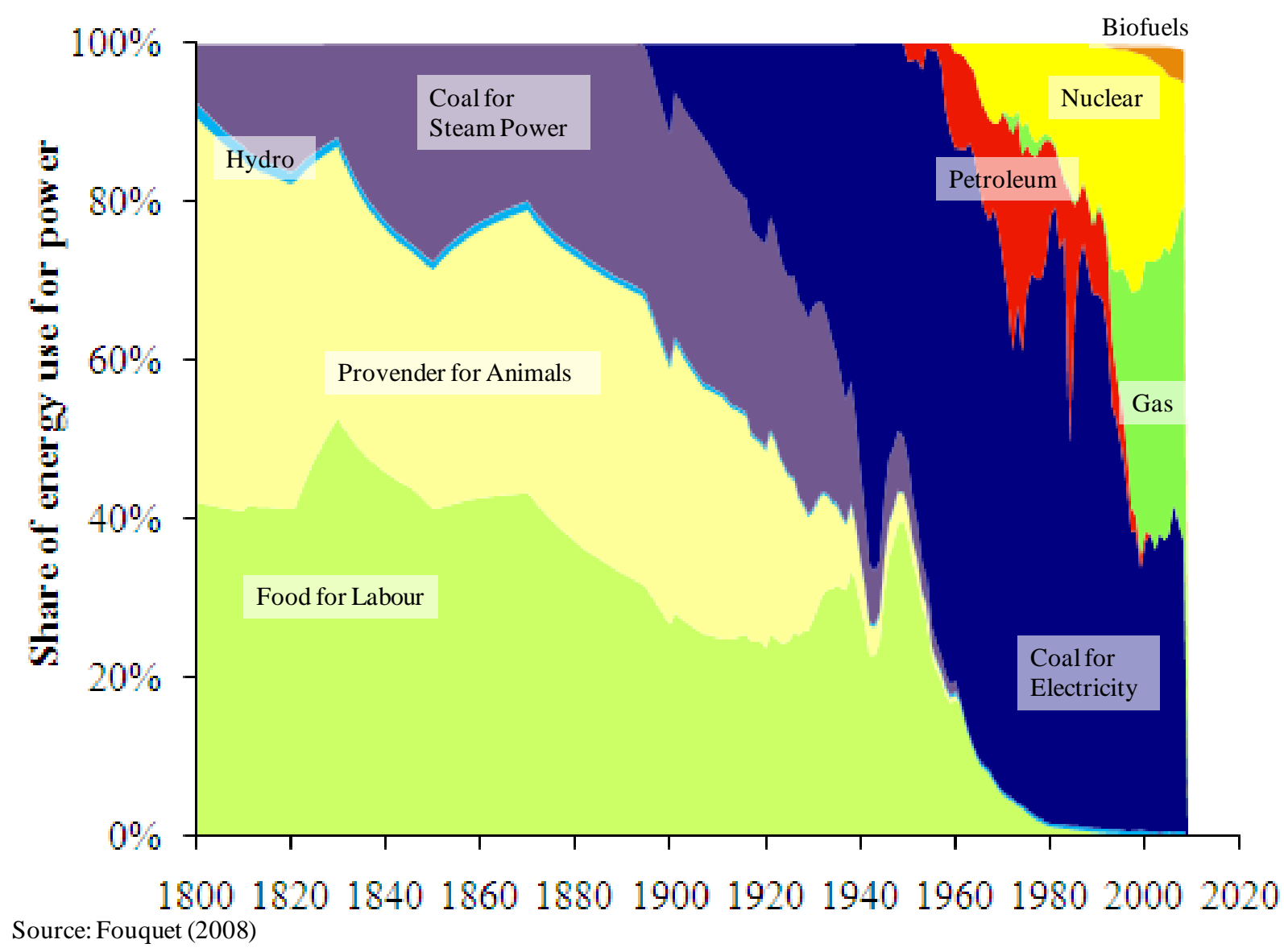

Also, the source of power production could be far from the user, allowing it to be generated in even greater concentration and enabling major economies of scale to be achieved. Coupled with the creation of a network of interconnected power stations, the price of electricity dropped dramatically between the 1880s and 1930s, becoming competitive with the steam engine by 1920 . Between 1920 and 1950, use of electricity for power purposes soared and displaced steam engines, making the latter obsolete. Until recently, though, coal remained the dominant primary source of energy for power. From the 1980s, nuclear power and natural gas have encroached on coal's dominance (see Figure 2). In 2008, renewable energy sources still only provide a small fraction of the overall power requirements in the United Kingdom. 


\subsection{Transport}

Until the twentieth century, transport, which has depended on a mobile and directed form of power, followed a similar path - oxen, horses, wind and steam. Yet, many of the early developments in transport services were not directly associated with energy substitutions, such as the reduction of risk on the high seas, the improvement of the quality of roads and rivers, the creation of canals and the consolidation of the stage coach network (Fouquet 2008 pp.139-190).

During the nineteenth century, however, new energy technologies transformed transport services. In 1804, Richard Trevithick built the first steam engine, offering an alternative source of mobile power to the horse and the sail. Yet, on land, it was not until George Stephenson's rocket in 1829 that the modern locomotive was born. After that, its spread was spectacular. By 1860, railways dwarfed horse-drawn freight volume and dominated passenger services (see Figure 3).

Early locomotives were relatively fuel inefficient. While this increased the cost, except for on short distances, pulling goods or passengers on a metal track required far less effort than along a road. This implied that horses pulling loads were far more inefficient than railways. And, while railways consumed great quantities of fuel, they could stop frequently to load-on more relatively cheap coal (compared to animal fodder).

In addition, railways radically changed transport services. They were first successful for freight services, carrying heavy goods during the Second Industrial Revolution, such as coal, iron and steel. Their main rival was the canal and the river network, but they were geographically constrained and, therefore, limited in their ability to distribute goods cheaply across an expanding economy. So, railways increased the reach and the scale of low-cost freight. For passengers, the railway network offered faster and cheaper travel, and an all-together different experience to the stage-coach.

On the seas, steam power, after its invention, was even faster to develop in niche areas. From the first ships built, in 1815, to 1830, entrepreneurs saw the potential of steam power and pushed its expansion. Yet, it took twice as long to dominate the general market than on land. Sailing ships improved efficiency and competitiveness after the introduction of steam ships, and grew in importance. Early steam ships were highly inefficient, requiring vast quantities of coal to fuel the voyage. Since they could less easily fuel-up on route than a train, the coal required displaced valuable space that might carry goods or passengers. It was not until major improvements in fuel efficiency in the latter part of the nineteenth century that it finally replaced the sailing ship (Dyos and Aldcroft 1969 p.241). Also, apart from improving reliability of arrival, because wind power was more intermittent, a steam and sailing ship 
offered similar services. Thus, its slower diffusion might also be because it did not revolutionise transportation in the same way as on land.

On roads, a number of different technologies had been tried to replace the horse. Steam-powered and electric vehicles were introduced in the nineteenth century. In 1803, Richard Trevithick drove his steam carriage through the streets of London, but few followed until the 1830s. Then, a powerful railway lobby managed to impose high toll duties on turnpikes and severe speed restrictions on road vehicles. Combined with their high costs, their use did not develop until the twentieth century (Bagwell 1974).

Figure 3. Share of Energy Consumption for Land, Sea and Air Transport in the United Kingdom (1800-2008)

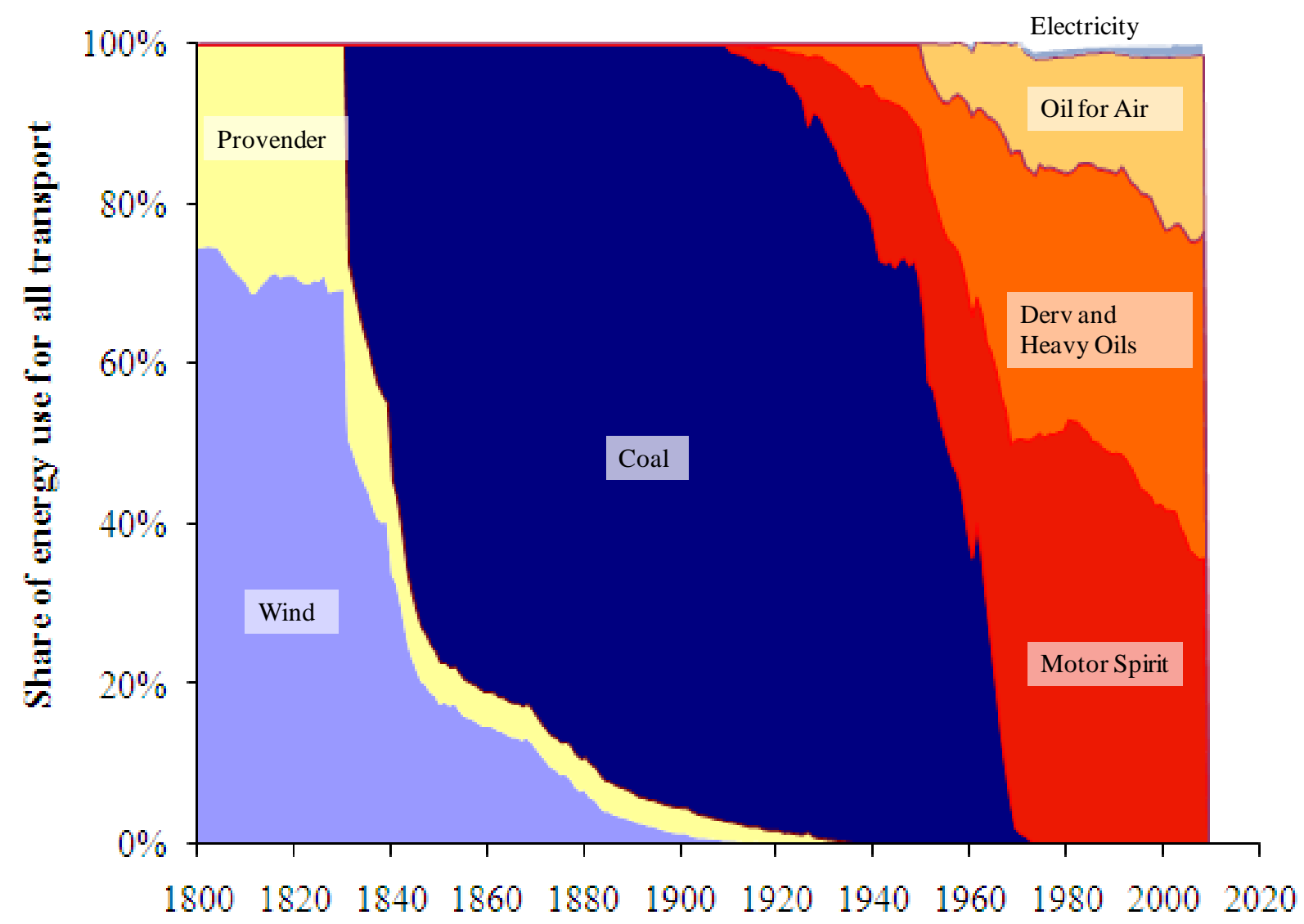

Source: Fouquet (2008)

In 1876, Nikolaus Otto developed the four-stroke combustion engine that became the basis for future road vehicles. Thirty-five years later, the Model-T Ford was introduced in Britain as the first 'affordable' car. By 1950, cars, buses and trucks had replaced railways as the dominant source of land transport both for passengers and freight. And, since then, on land, on water and in the air, petroleum (in all its forms) has become the energy source driving the transport sector (see Figure 3). 


\subsection{Lighting}

In the lighting sector, the dominance of gas over candles took from the 1810s until about 1850 forty years (see Figure 4). The lighting experience was radically different (Schivelbusch 1988) and allowed a great increase in lighting consumption (Fouquet and Pearson 2006).

In terms of marginal (or fuel) costs, gas was from the beginning cheaper than using candles. Yet, the high installation costs of pipes prohibited many households. For segments of the market (principally poorer households), gas made few inroads in the lighting market until the end of the nineteenth century, when companies installed the pipes and metered households' consumption. In addition to declining prices and efficiency of gas lighting technology, easier access to gas supply and a growing middle class with more savings to invest in installation and equipment increased the dominance of gas (Falkus 1967)

Figure 4. Share of Energy Consumption for Lighting in the United Kingdom (1800-2008)

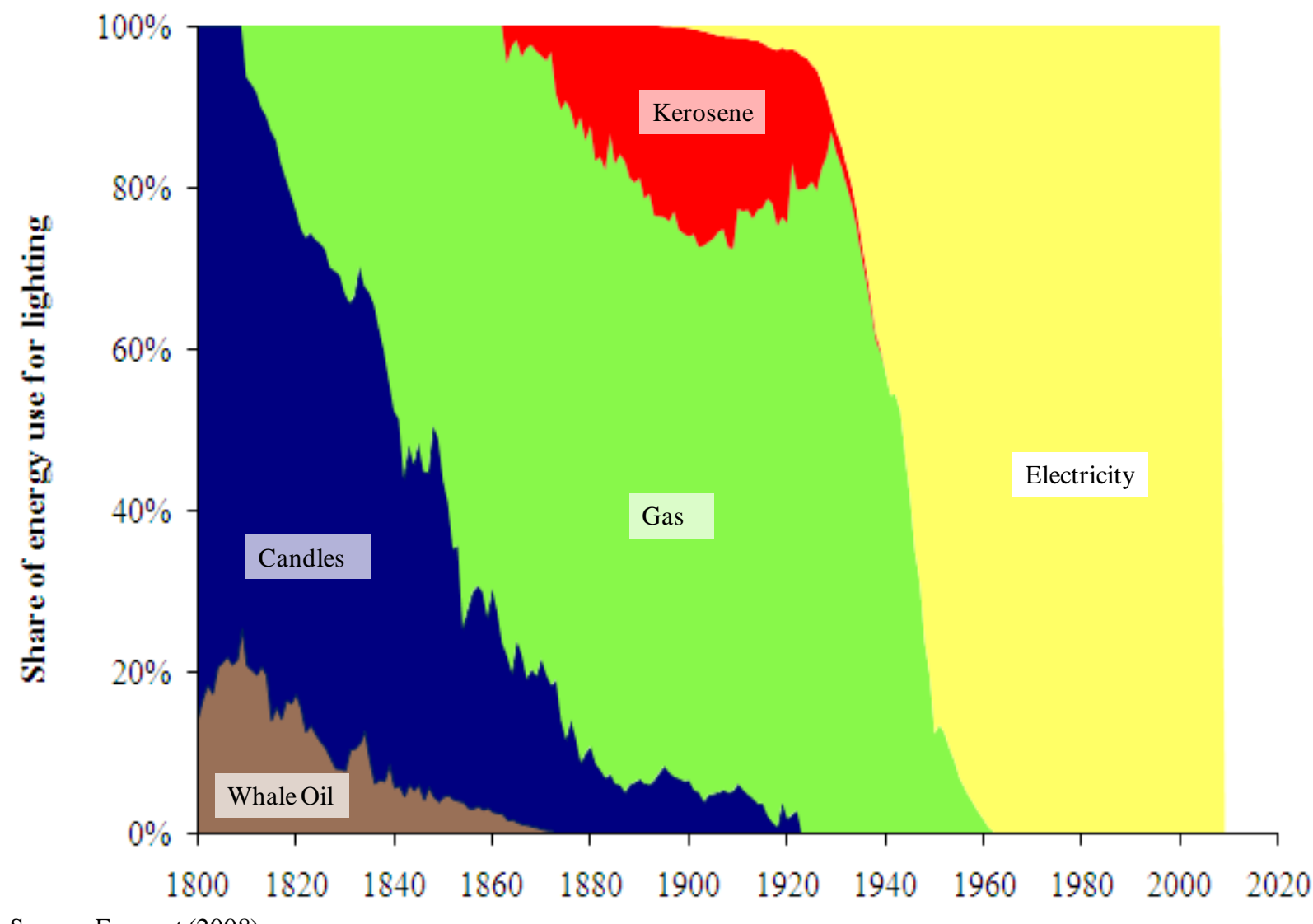

Source: Fouquet (2008)

Instead, from the mid-nineteenth century, paraffin (or kerosene) was used because of the minimal expenditure on lamps and fuel access. Kerosene-lighting was cheaper than candle-lighting practically 
from its introduction; and by the 1890s, it was starting to compete with gas lighting in terms of fuel costs. Yet, kerosene, even at its peak in the early twentieth century (fifty years later), was never more than onefifth of the total market for lighting. Despite enabling poorer populations major improvements in lighting standards, it would be inappropriate to consider the introduction of kerosene as much more than a fuel and technological substitution.

The energy source that ultimately dominated took the longest to be developed and refined. The electric arc was demonstrated for the first time in 1810 by Humphrey Davy. Yet, it took a number of further inventions, including the dynamo, for the commercialisation of electric lighting to begin. The replacement of gas by electricity started in the 1880s, and was gradual. Electric lighting technology (arc light) was first only appropriate for outdoors. It met a specific market. Also, the gas lighting technology improved dramatically (a type of 'sailing ship' effect). Then, as incandescent bulbs became available,

electricity provided a growing segment of the market. Yet, it was not until the 1920s that electric lighting became cheaper than gas lighting. Thus, the transition took from the 1880s until the 1950s - seventy years.

\section{Analysis of Energy Substitutions and Transitions}

Table 1 summarises key information about the energy substitutions and transitions discussed above. It indicates the nature of the changes that occurred, the main drivers and catalysts for the diffusion, and the duration of the innovation chain and the diffusion process. Before reviewing duration of the substitutions and transitions, it is worth discussing the nature of the changes that took place.

This table combines broad and more specific sectors. For heating, households and the iron industry required only one technological solution, whereas 'manufacturing' refers to an aggregation which included many different solutions. For lighting, consumption is the total for the whole economy. Of the fourteen energy substitutions or transitions, two were within the traditional energy economy, eight were associated with the transition from the traditional energy economy to the modern energy system and four (one for each service, although there were others) involved a switch from one fossil fuel to another. This shows that the energy transition from traditional energy to fossil fuels, which is often considered a single event (as shown in Figure 5), was complex, involving numerous services and sectors at different times between 1500 and 1920 . 
Table 1. A Summary of Energy Substitutions and Transitions

\begin{tabular}{|c|c|c|c|c|c|}
\hline Substitution (Original-New) & Service & $\begin{array}{c}\text { Nature } \\
\text { of } \\
\text { Changes }\end{array}$ & $\begin{array}{c}\text { Probable Key Factors } \\
\text { in Diffusion }\end{array}$ & $\begin{array}{l}\text { Approx. Period } \\
\text { (Innovation to } \\
\text { Dominance) }\end{array}$ & $\begin{array}{l}\text { Approx. Period } \\
\text { (Diffusion to } \\
\text { Dominance) }\end{array}$ \\
\hline Residential Woodfuel-Coal & Heating & $\begin{array}{l}\text { Supply } \\
\text { Energy } \\
\text { Service }\end{array}$ & $\begin{array}{l}\text { D: Price of Energy } \\
\text { C: Invention }\end{array}$ & $\begin{array}{l}1500-1800 \\
\text { (300 years) }\end{array}$ & $\begin{array}{l}1580-1800 \\
\text { (220 years) }\end{array}$ \\
\hline Iron Woodfuel-Coal & Heating & $\begin{array}{l}\text { Supply } \\
\text { Energy } \\
\text { Service }\end{array}$ & $\begin{array}{l}\text { D: Price of Energy } \\
\text { C: Invention } \\
\text { C: Efficiency }\end{array}$ & $\begin{array}{l}1709-1790 \\
\text { (81 years) }\end{array}$ & $\begin{array}{l}1750-1790 \\
(40 \text { years) }\end{array}$ \\
\hline Manufacturing Woodfuel-Coal & Heating & $\begin{array}{l}\text { Supply } \\
\text { Energy } \\
\text { Service }\end{array}$ & $\begin{array}{l}\text { D: Price of Energy } \\
\text { C: Inventions }\end{array}$ & $\begin{array}{l}1300-1700 \\
\text { (400 years) }\end{array}$ & $\begin{array}{l}1550-1700 \\
\text { (150 years) }\end{array}$ \\
\hline Residential Coal-Gas & Heating & $\begin{array}{l}\text { Supply } \\
\text { Energy } \\
\text { Service }\end{array}$ & $\begin{array}{l}\text { D: Better Service } \\
\text { C: Price of Energy }\end{array}$ & $\begin{array}{l}1880-1975 \\
(95 \text { years) }\end{array}$ & $\begin{array}{l}1920-1975 \\
\text { (55 years) }\end{array}$ \\
\hline Ox-Horse & Power & Energy & D: Efficiency & $\begin{array}{l}900-1600 \\
\text { (700 years) }\end{array}$ & $\begin{array}{l}1070-1600 \\
\text { (530 years) }\end{array}$ \\
\hline Animals-Mills & Power & $\begin{array}{l}\text { Supply } \\
\text { Energy } \\
\text { Service }\end{array}$ & $\begin{array}{l}\text { D: Different Service } \\
\text { C: Econ. of scale }\end{array}$ & $\begin{array}{l}700-1350 * \\
\text { (650 years) }\end{array}$ & $\begin{array}{l}1000-1350 * \\
\text { (350 years) }\end{array}$ \\
\hline Animals-Steam & Power & $\begin{array}{l}\text { Supply } \\
\text { Energy } \\
\text { Service }\end{array}$ & $\begin{array}{l}\text { D: Different Service } \\
\text { C: Efficiency }\end{array}$ & $\begin{array}{l}1710-1920 \\
\text { (210 years) }\end{array}$ & $\begin{array}{l}1830-1920 \\
(90 \text { years })\end{array}$ \\
\hline Steam-Electricity & Power & $\begin{array}{l}\text { Supply } \\
\text { Energy } \\
\text { Service }\end{array}$ & $\begin{array}{l}\text { D: Better Service } \\
\text { C: Econ. of scale }\end{array}$ & $\begin{array}{l}1821-1950 \\
\text { (139 years) }\end{array}$ & $\begin{array}{l}1920-1950 \\
(30 \text { years) }\end{array}$ \\
\hline Horses-Railways & Land Transport & $\begin{array}{l}\text { Supply } \\
\text { Energy } \\
\text { Service }\end{array}$ & $\begin{array}{l}\text { D: Better Service } \\
\text { C: Price of Service }\end{array}$ & $\begin{array}{l}1804-1860 \\
\text { (54 years) }\end{array}$ & $\begin{array}{l}1830-1860 \\
(30 \text { years) }\end{array}$ \\
\hline Sail-Steam Ship & Sea Transport & $\begin{array}{l}\text { Supply } \\
\text { Energy } \\
\text { Service }\end{array}$ & $\begin{array}{l}\text { D: Better Service } \\
\text { C: Efficiency }\end{array}$ & $\begin{array}{l}1815-1890 \\
(75 \text { years) }\end{array}$ & $\begin{array}{c}1830-1890 \\
(60 \text { years })\end{array}$ \\
\hline Railways-Combustion Engine & Land Transport & $\begin{array}{l}\text { Supply } \\
\text { Energy } \\
\text { Service }\end{array}$ & $\begin{array}{l}\text { D: Better Service } \\
\text { C: Efficiency }\end{array}$ & $\begin{array}{l}1876-1950 \\
\text { (74 years) }\end{array}$ & $\begin{array}{l}1911-1950 \\
(39 \text { years) }\end{array}$ \\
\hline Candles-Gas & Lighting & $\begin{array}{l}\text { Supply } \\
\text { Energy } \\
\text { Service }\end{array}$ & $\begin{array}{l}\text { D: Better Service } \\
\text { C: Price of Energy } \\
\text { C: Efficiency }\end{array}$ & $\begin{array}{l}1800-1850 \\
(50 \text { years) }\end{array}$ & $\begin{array}{l}1810-1850 \\
\text { (40 Years) }\end{array}$ \\
\hline Candles-Kerosene & Lighting & $\begin{array}{l}\text { Supply } \\
\text { Energy }\end{array}$ & $\begin{array}{l}\text { D: Price of Energy } \\
\text { C: Discovery }\end{array}$ & $\begin{array}{l}1850-1900 * \\
(50 \text { years) }\end{array}$ & $\begin{array}{l}1860-1900 * \\
(40 \text { Years })\end{array}$ \\
\hline Gas-Electricity & Lighting & $\begin{array}{l}\text { Supply } \\
\text { Energy } \\
\text { Service }\end{array}$ & $\begin{array}{l}\text { D: Better Service } \\
\text { C: Price of Energy } \\
\text { C: Efficiency }\end{array}$ & $\begin{array}{l}1810-1935 \\
(125 \text { years })\end{array}$ & $\begin{array}{l}1880-1935 \\
\text { (65 years) }\end{array}$ \\
\hline
\end{tabular}

\footnotetext{
* Its peak share, as it did not become the dominant source of energy. D: main driver for adoption; C: main catalyst for adoption (especially if there was relatively long delay between invention and adoption).
} 
Three major changes were identified to occur in the process of switching energy sources: the supply network, the energy source and the service provided. Naturally, all experienced changes in the energy source used. The shift from the steam engine to electricity actually used the same primary fuel, but the power came from a different energy source. Second, in all cases, except possibly the ox to horse switch, the method of supplying the energy source needed to be changed. This generally involved new producers, distributors and retailers - often (and particularly since the Industrial Revolution) requiring major infrastructure investments, such as the gas, railway or electricity networks. Based on the earlier definition, switches requiring changes to the energy system can be defined as energy transitions, rather than substitutions. Third, in all but a couple of cases, consumers experienced major changes in the energy services provided. That is, they consumed significantly larger quantities of services (Fouquet 2008).

\section{Figure 5. Share of Primary Energy Consumption in the United Kingdom (1500-2000)}

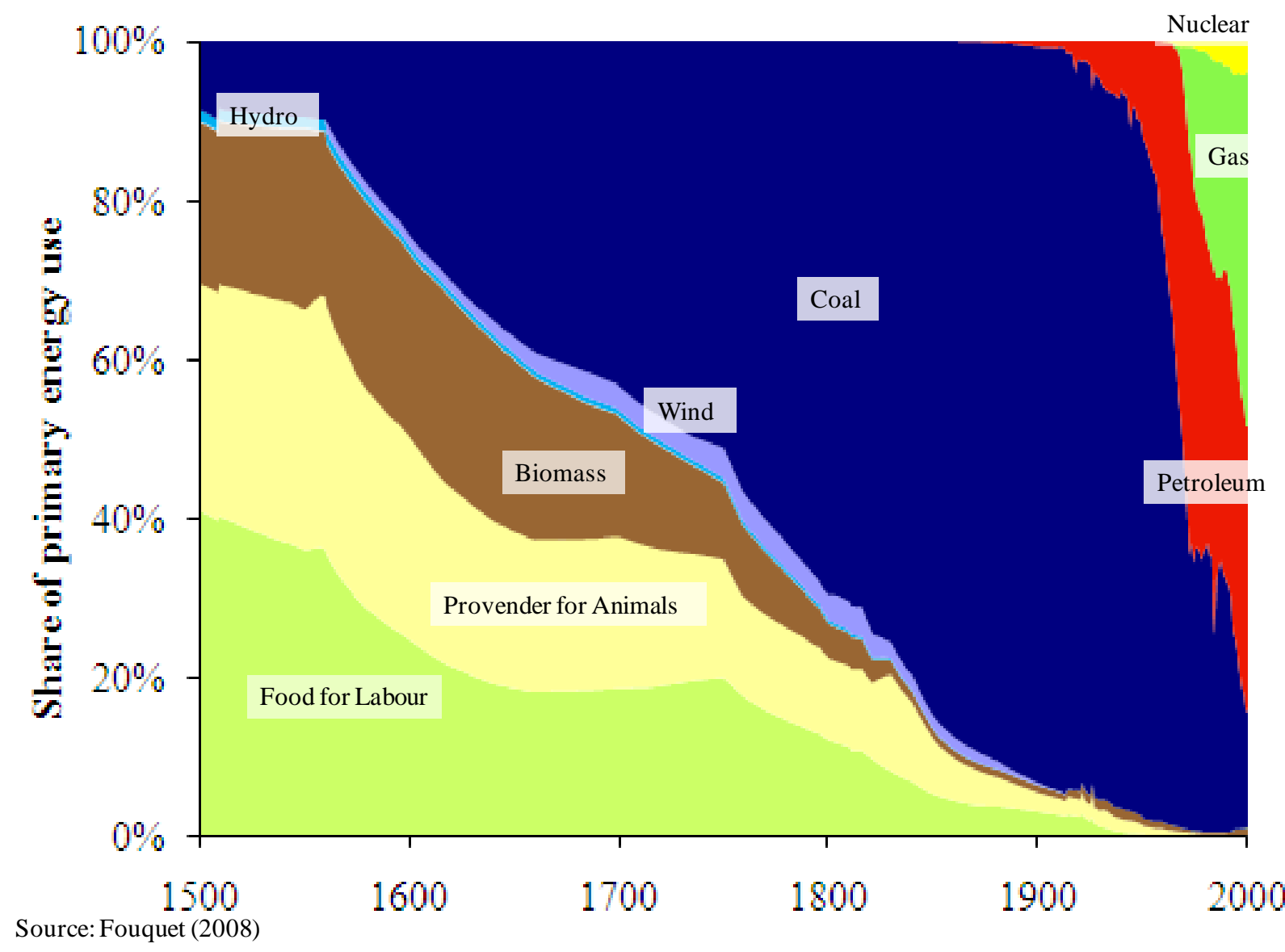

In the next column, Table 1 presents the drivers and catalysts for transitions (based on the author's judgement, see Fouquet 2008 for a more in-depth analysis of each case). In all cases, cheaper or better services were key to the switch. In a majority of cases, the driver was better or different services. 
The steam engine enabled entrepreneurs to boost production, not limited by humans and animals or by the location of flowing water. Electricity radically altered the production process from belts centrally-driven by a steam engine to numerous machines run by electricity and potentially controlled by the worker. Railways and cars also transformed the provision of transport services, allowing a faster service and a more flexible and private form of transport, respectively. Gas lighting was easier to use and less dangerous. Electric lighting was much easier to use.

A new energy source or technology often provided the same service (i.e. heating, power, transport or light) in a way that offered superior or additional characteristics (e.g. easier, cleaner or more flexible to use). But, frequently, the high price of the service (i.e. the combined energy price and efficiency) made it only accessible to a few consumers. The energy price or its inefficiency at converting energy into the service limited its market to a niche of consumers willing to pay a premium for those characteristics.

For the market share to have grown, the energy price needed to fall or the technology's efficiency had to have been improved in the niche market to have been competitive with the incumbent technology on the price of the service alone. And, the declining price of energy or greater efficiency acted as the catalysts for the diffusion of the technology and the new energy source through the broader market.

In seven cases, improvements in efficiency were the proposed catalyst for transitions. Greater technical efficiency could have been the driver (rather than the catalyst) for a switch. However, interestingly, only in the case of the change from ox to horse was efficiency the (suggested) driver.

In three instances, the price of a new (or competing) energy source was the catalyst. That is, the technology offered better or extra attributes, and a decline in the energy price created the incentive for large share of consumers to adopt. In four other cases, the cheaper price of energy was the driver for the switch, and the invention of a new technology was the catalyst. The various sectoral transitions from woodfuels to coal were driven by cheaper services. For domestic purposes, the price of coal was sufficiently low to override the efficiency losses of coal-using equipment and inferior service. The early fireplaces provided less heating per unit of energy and chimneys were especially poor at extracting smoke. In the iron industry of the eighteenth century, the price of coal drove the change but efficiency improvements to the new invention were necessary to make it attractive and for the industry to expand and play a central role in the Industrial Revolution. For kerosene lighting, it was the discovery, extraction and retailing of large reserves of petroleum that provided the catalyst.

In two final cases, again the service was provided in a better way, and economies of scale in production offered the catalyst for the switch. For both the switch from animals to mills, and steam to 
electricity, it was the scale upon which the technology was used that made it attractive to power producers.

In summation, in nine of the fourteen cases, a better service was the proposed driver for the energy transition. In the five other cases, it was directly the cheaper energy service that was the driver (four of which, it was a cheaper energy source the reason for the switch). Three of those were for changes in the heating market. Especially for transport and lighting, pivotal to an energy transition was that the new energy source and technology offered greater or additional characteristics that became attractive to the whole market as the price of energy fell and technical efficiency improved. For power, as economies of scale in production were achieved, major adoption took place. Nevertheless, in all cases, a lower price of energy service was necessary to achieve the energy transition.

So far, the price of the service has been considered as the marginal cost of production. Yet, fixed or capital costs are clearly important. Especially for power provision, high capital costs have traditionally limited investment in steam engines or electricity generators to large firms - with important repercussions for the nature of work and the economy. Similarly, the high fixed costs of gas lighting implied poorer households could not switch away from tallow candles, despite the relatively high price of candlelight, until kerosene and its cheap lamps were available in the second half of the nineteenth century. Then, at the end of the century, gas companies installed gas pipes in poorer homes with pre-paid meter schemes and poorer households were able to use gas instead of candles or kerosene. In general, high or low capital costs relative to equipment used for fossil fuel combustion have been major barriers or incentives for their uptake.

Another important factor is the incumbent companies' responses to competition from new entrants. Companies threatened by a new entrant are likely to find ways to improve their service or hinder the entrant's uptake. When steam engines became a potential prime mover on the seas, sailing ship became far more effective - the 'sailing ship effect'. The gas suppliers and related technology manufacturers became creative especially once electricity was a threat in the lighting market. Alternatively, the 'stage coach effect' can occur - when companies started building a railway network in the early nineteenth century, stage coach companies increased their prices on lines not accessible by rail to make back their horse and coach investments as quickly as possible (Fouquet 2008 p.164).

Table 1 also shows the period between key inventions and the uptake of the energy source, and the duration of the diffusion as the source reaches dominance for that particular sector or service. Naturally, many of the dates related to technological inventions are slightly arbitrary, since they are built 
on the backs of other inventions. Nevertheless, they provide some indication of the duration of the innovation chain (from invention to uptake to dominance).

The `innovation chain` (i.e. from innovation to uptake to diffusion) for an individual sector or service could take hundreds of years. The faster experiences took a minimum of fifty years. The shortest period between invention and uptake was ten years. This occurred in the cases of gas and kerosene lighting. They benefitted from a great demand for the energy source and technologies given that the incumbent energy source was relatively primitive, the technology was seen to be superior and, at the time, there was a growing middle class with income to spend on services, such as lighting. They also experienced short diffusion phases - 40 years. All the ingredients were right from the start: as well as the high value placed on these lighting sources, the price of gas and kerosene lighting favoured them over candles, and prices fell (greater energy efficiency and lower fuel prices) with diffusion (Fouquet and Pearson 2006).

There is evidence that earlier innovations and diffusions were slower than more recent ones. This is especially true comparing transitions before and after the Industrial Revolution. Indeed, the average durations of a pre-Industrial Revolution innovation chain and diffusion were more than 500 years and 300 years respectively. During or after the Industrial Revolution, the average innovation and diffusion length were 95 years and 45 years respectively. A basic regression analysis rejects the possibility (with 99\% confidence) that the lengths before and after the Industrial Revolution were the same. This suggests that the full innovation chain was 400 years shorter and the diffusion chain was 250 years less for transitions that occurred during or after the Industrial Revolution. A possible explanation is the transformation of markets associated with this period, enhancing the dissemination of information and the access to products. However, no trend appears since the mid-eighteenth century. Thus, the Industrial Revolution led to a step-jump in the speed of transitions.

The factor that drives the innovation chain and diffusion appear to influence duration. The main drivers were the price of energy (four cases) and better services (nine cases). The average innovation chain duration was almost identical for both drivers (210 years). But, the average diffusion of servicedriven energy sources and technologies was faster (84 years) than when energy prices were the driver (112 years).

However, focussing on energy transitions during or after the Industrial Revolution, the results change. The average duration of the full innovation chain is considerably longer (138 years) if the main driver for the transition is added value to the service rather than a decline in prices (65 years). However, 
the average diffusion phase is only slightly longer (45 years rather than 40 years). It should be noted that these influences were not statistically significant - perhaps because of the smaller data set.

A likely explanation for this difference between drivers is that better quality services (e.g. greater flexibility associated with using electricity rather steam engines or using cars rather than railways) are not sufficient for uptake. If the main driver is only a better quality of energy service, consumers may delay uptake until the price of energy or efficiency become favourable. Once the conditions are right diffusion was as rapid as if the price of energy was the driver. Ultimately, favourable energy service prices (i.e. combined price of energy and efficiency) are necessary for uptake and diffusion.

\section{A Gradual Process to Low Carbon Energy}

Based on this sample, a frequent driver of past energy transitions was better or additional services (e.g. easier, cleaner or more flexible to use) associated with the new energy sources and technologies. This, in principle, is good news for those with ambitions to move towards a low carbon economy. Low carbon energy sources and technologies should emit considerably less greenhouse gases per unit of energy used or of service provided. So, they might be seen to provide a better or additional service.

However, it does depend on whether consumers or governments place value and are willing to pay for the better service. Historically, early adopters have often been willing to pay considerably more for superior or new attributes. The switch to electric lighting was an extreme example, where certain customers - especially, restaurants, theatres and wealthy house owners - were willing to pay many times more for the exclusive features of electric lighting. A growing number of consumers appear to be willing to pay for low-polluting energy sources (Fouquet 1998, Longo et al 2008). A question mark remains about whether the majority of consumers would be willing to pay more.

In addition to their lower carbon dioxide emissions, these energy sources and technologies may provide other better or additional services. Alternatively, they may be inferior in some ways. This depends on physical, chemical, technical, economic, social and environmental factors. There is no a priori rule about whether low carbon sources and technologies would provide better or worse other services, and should be considered on an individual case-by-case basis. For instance, wind power intermittency has been seen as a barrier to major uptake. Similarly, the power density, which refers to the rate of energy production per square metres required, of biomass is very low compared with fossil fuels, which need such little land (Smil 2003). Also, the energy return on investment (EROI) and energy surplus are exceptionally high for oil and gas, especially compared to alternative energy sources, such as biomass. 
These additional detrimental features could play a pivotal role in the success or failure of a transition (Cleveland 2008).

While better or additional services are a common way to create a niche market, it is not sufficient for a major switch. In all cases of service-driven transitions, lower prices were crucial. However, it is the cost of generating the service that is vital, not necessarily the energy price (Fouquet 2010). If the low carbon fuel is twice as expensive, but the efficiency of the technology is three times greater, its service is cheaper and stands a good chance of adoption. So, the price of energy services will be crucial for determining the likelihood of switching to low carbon energy sources and technologies.

The pricing schemes introduced for carbon dioxide emissions (whether in the form of taxes or tradable permits) increase the cost of generating services from fossil fuels. So, naturally, they will favour the uptake of low carbon fuels. Taxes are likely to provide more certainty than tradable permit schemes for consumers making investment decisions. Tradable permits are subject to considerable volatility, and will only drive decisions as permit supply is genuinely constrained and demand grows (Abadie et al 2009).

Also, the fixed costs of producing energy services are important for the successful uptake of low carbon technologies. Factors that will lower the fixed costs can favour their diffusion. Irrespective of the technology and its costs, it benefits from economies of scale in production, enabling the fixed costs of producing equipment to decline as its total production grows. In niche or protected markets, such as higher valued low carbon energy sources, equipment production can slowly expand and equipment prices can gradually fall.

The previous section showed that the energy transition from traditional energy to fossil fuels involved numerous services and sectors over more than 400 hundred years. Looking forward, for most services, a transition to a low carbon economy is also likely to be very slow. Technological solutions may not be easily available. In the United Kingdom, and in many countries, heating use has shifted to natural gas, the lowest carbon-polluting fossil fuel, and direct substitutes are not obvious. Power has been increasingly generated by gas turbines. Renewable sources may provide a growing share, but are likely to be constrained by physical and technical limits (Cleveland 2008, Pollitt 2010). The dependence on gas for both heating and power will raise risks of higher prices, which could encourage a transition to non-fossil fuels. In the transport sector, oil remains the dominant source - electricity or hydrogen may offer a low carbon alternative, if connected to renewable source. However, in 2010, their ability to replace the internal combustion engine is very much uncertain. 
Low carbon energy sources and technologies are likely to provide better and additional services. Based on past experiences, such a transition could involve a long period between the invention and the diffusion of the technology. For instance, although valued alternatives to fossil fuels exist, in most cases, they are still more expensive at producing energy services. Based on experiences since the Industrial Revolution, the average innovation chain for low carbon energy sources would be over one hundred years.

Yet, as mentioned before, because they provide valued extra attributes, they could remain in niche or protected markets. This is important because it allows the energy sources and technologies to 'survive' at a higher price than the incumbent sources and technologies. Economies of scale, learning by doing and technological refinements can take place in a relatively protected market. If, eventually, prices of the energy services produced by these alternatives fall sufficiently they can compete fully with the incumbent - and, if sufficiently valued, replace it. So, although it may take a long time (if at all), low carbon technologies are valued and are likely to be protected from the harsh realities of full market competition, until ready. Similarly, from the examples of the eighteenth century onwards, the average diffusion for low carbon sources should be just under 50 years.

Nevertheless, it was noted that transitions were faster during or after the Industrial Revolution, and it was suggested that one reason for this might be the greater development of markets and faster spread of information. It could be expected that market development and information dissemination since the introduction of Information and Communication Technology (ICT) has increased. Thus, it could be argued that future energy transitions, all other things being equal, will be faster than the historical average.

However, the threat of a transition to low carbon sources and technologies will generate responses from the fossil fuel supply companies. It is too early and complex to identify the strategies they will develop, but it is likely to be more 'sailing ship effect' than 'stage coach effect', implying that they will become increasingly competitive and harder to replace.

Also, if a transition to low carbon fuels does occur, it may not necessarily lead to a decline in fossil fuel consumption. For instance, woodfuel consumption continued long after coal was the dominant fuel for heating. Similarly, coal has been on the decline in the United Kingdom since the middle of the twentieth century, but power stations still use large amounts. Despite oil having been replaced in most sectors since the 1970s, it continues to provide the vast majority of requirements for transport services. The transition would reduce the demand for fossil fuels, thus, reducing their prices and increasing their competiveness - and, making the obsolescence of fossil fuels very difficult. 
And, when new technologies provided the service with greater energy efficiency (which may occur), they allowed significantly cheaper services. These led to dramatic increases in the consumption of services. From a combination of rising economic activity and disposable income, declining energy prices and the rebound effect, greater energy consumption ensued (Fouquet 2008). So, it is very likely that the transition to a low carbon economy will involve greater levels of overall consumption.

\section{Conclusions}

The purposes of this paper were to examine past energy transitions by sector and service and to identify some commonalities that may be useful for anticipating future transitions.

The focus was on transitions in the United Kingdom. This country was the first to make the transition from traditional energy sources to fossil fuels. The shift to low carbon technologies has not yet occurred, so, no country can benefit from others' experience and technologies, which would ease and accelerate a transition. In that respect, studying the United Kingdom's experience offers a unique perspective that is similar to a possible transition to a low carbon economy.

The emphasis in this paper was in stressing that the energy transition from traditional energy sources to fossil fuels, which is often considered a single event, was complex, involving numerous services and sectors at different times between 1500 and 1920. For heating, different technologies for households and many industries, such as for iron smelting, needed to be invented, refined and adopted that could use coal rather than woodfuels. Similarly, for power and transport, the replacement of horses with steam engines depended on the development of equipment specific to each industry and on the appropriate conditions for adoption. And, in the lighting market during the nineteenth century, different new energy sources and technologies were developed for separate segments of the population, which eventually became the main fuels of the economy at the end of the twentieth and beginning of the twentyfirst century.

The important drivers for the energy transitions were the opportunity to produce cheaper or better energy services. In a majority of cases, a successful new energy source or technology provided the same service (i.e. heating, power, transport or light) with superior or additional characteristics (e.g. easier, cleaner or more flexible to use). Often, after their introduction, the price of the service they provided was higher than from the incumbent energy source. This implied that their adoption was limited to niche markets. However, because some consumers were willing to pay a premium for those better or additional characteristics, these technologies could be refined and costs could fall gradually. Once the price of the 
service fell sufficiently (either because the energy efficiency improved or the price of energy declined), their adoption was almost as swift as in cases when cheaper services drove the transitions. Still, since the Industrial Revolution, it took, on average, nearly fifty years for energy transitions (i.e. the diffusion of energy sources and technologies) to unfold.

The fact that many transitions were driven by additional or superior characteristics is good news for a possible move towards a low carbon economy. The greater the consumer's and government's willingness to pay for climate stability, the more protected will be the niche market enabling low carbon energy sources and technologies to be developed and refined. However, there are a number of unfavourable characteristics, such as intermittency and low power density, which could delay or limit diffusion. Ultimately, though, for a transition to occur, low carbon energy sources and technologies have to provide cheaper energy services. Naturally, internalisation processes, such as carbon taxes or tradable permit schemes, can improve their competitiveness. At the same time, the threat of a transition to low carbon sources and technologies will probably encourage fossil fuel supply companies to be more competitive, delaying any uptake. Thus, for most services and sectors, a transition to a low carbon economy is likely to be slow and is unlikely to occur simultaneously in all sectors for all services. Also, such a transition may not necessarily reduce fossil fuel consumption for a very long time.

This paper suggests that, based on past experiences, carbon dioxide emissions are likely to continue to increase for many years, raising greenhouse gas concentrations and intensifying the process of climate change. Action today will probably have a very long lag time (probably decades and maybe longer). This implies that early action and favourable conditions may be warranted to steer any transition to a low-carbon economy.

\section{References}

Abadie, L.M., J.M. Chamorro and M. Gonzáez-Eguino (2009) Optimal Investment in Energy Efficiency under Uncertainty. BC3 Working Paper Series 2009-11. Basque Centre for Climate Change (BC3). Bilbao, Spain.

Bagwell, P.S. (1974) The Transport Revolution from 1770. B.T. Batsford. London.

Barker, T., S. Scrieciu, Serban, T. Foxon (2008) Achieving the G8 50\% target: modelling induced and accelerated technological change using the macro-econometric model E3MG. Climate Policy 8(S) S30S45.

Barnes, D.F. and W.M. Floor (1996) 'Rural energy in developing countries: a challenge for economic development.' Annual Review of Energy and the Environment 21 497-530. 
Batoletto, S. and M.d.M. Rubio (2008) 'Energy Transition and CO2 Emissions in Southern Europe: Italy and Spain (1861-2000).’ Global Environment 2 46-81

Cipolla, C.M. (1962) The Economic History of World Population. Pelican Books. London.

Cleveland, C.J. (2008) ‘Energy transitions past and future’’ Encyclopedia of Earth.

Devine, W. (1983) 'From shaft to wires: historical perspective on electrification.' Journal of Economic History 43(2) 347-72.

Dyos, H.J. and D.H. Aldcroft (1969) British Transport: An Economic Survey from the Seventeenth Century to the Twentieth. Leicester.

Edmonds, J., L. Clarke, M. Wise, H. Pitcher, S. Smith (2008) Implications for the USA of stabilization of radiative forcing at $3.4 \mathrm{~W} / \mathrm{m} 2$. Climate Policy $8(\mathrm{~S})$ S76-S92.

Gales, B., A. Kander, P. Malanima and M. Rubio (2007) "North versus South: Energy transition and energy intensity in Europe over 200 years", European Review of Economic History 11(2) 219-53.

Falkus, M.E. (1967). ‘The British gas industry before 1850.’ Economic History Review 20 494-508.

Fouquet, R (1998) 'The United Kingdom demand for renewable electricity in a liberalised market.' Energy Policy 26(4) 281-94.

Fouquet, R. (2008) Heat Power and Light: Revolutions in Energy Services. Edward Elgar Publications. Cheltenham and Northampton, MA.

Fouquet, R. (2010) Divergences in the Long Run Trends in the Price of Energy and of Energy Services. BC3 Working Paper Series 2010-03. Basque Centre for Climate Change (BC3). Bilbao, Spain.

Fouquet, R. and P.J.G. Pearson (1998) 'A thousand years of energy use in the United Kingdom.' The Energy Journal 19(4) 1-41.

Fouquet, R and Pearson, P.J.G. (2006), 'Long Run Trends in Energy Services: The Price and Use of Lighting in the United Kingdom, 1300-2000.’ The Energy Journal 25(1) 139-77.

Foxon T. and P.J.G. Pearson (2007) 'Policy Processes for Low Carbon Innovation in the UK: Successes, failures and lessons.’ Energy Policy 351539 - 1550

Foxon, T.J., J. Köhler, C. Oughton (2008) Innovation for a Low Carbon Economy: Economic, Institutional and Management Approaches. Edward Elgar Publ. Cheltenham and Northampton, MA.

Gales, B., A. Kander, and P. Malanima, and M.d.M. Rubio (2007) 'North vs South: Energy Transition and Energy Intensity in Europe over 200 years.’ European Review of Economic History 11(2) 219-53

Geels, F.W. (2002) 'Technological transitions as evolutionary reconfiguration processes: A multi-level perspective and a case-study.’ Research Policy 31(8/9) 1257-74. 
Geels, F.W. (2005) Technological Transitions and System Innovations. Edward Elgar. Cheltenham, UK and Northampton, MA, USA.

Gross, R. (2004) 'Technologies and innovation for system change in the UK: status, prospects and system requirements of some leading renewable energy options’ Energy Policy 321905 - 1919

Grubb, M., T. Jamasb and M.G. Pollitt (2008a) Delivering a Low-Carbon Electricity System: Technologies, Economics and Policy. Cambridge: Cambridge University Press.

Grubb, M., N. Haj-Hasan and D. Newbery (2008b) in Grubb, M., T. Jamasb and M.G. Pollitt (eds.) Delivering a Low-Carbon Electricity System: Technologies, Economics and Policy. Cambridge: Cambridge University Press.

Grübler, A., N. Nakicenovic and D.G. Victor (1999) 'Dynamics of energy technologies and global change.' Energy Policy 27 247-80.

Grübler, A. (2008) 'Energy transitions.' Encyclopedia of Earth.

Heltberg, R. (2004) 'Fuel switching: evidence from eight developing countries.' Energy Economics 26(5) 869-887.

Jamasb, T., W.J. Nuttall, M.G. Pollitt and A. Maratou (2008) in Grubb, M., T. Jamasb and M.G. Pollitt (eds.) Delivering a Low-Carbon Electricity System: Technologies, Economics and Policy. Cambridge: Cambridge University Press.

Haas, R., N. Nakicenovic, A. Ajanovic, T. Faber, L. Kranzl, A. Müller and G. Resch (2008) 'Towards sustainability of energy systems: A primer on how to apply the concept of energy services to identify necessary trends and policies.’ Energy Policy 36(11) 4012-4021.

Jefferson, M. (2008) ‘Accelerating the transition to sustainable energy systems’ Energy Policy 36(11) 4116-4125.

Kanefsky, J.W. (1979) The Diffusion of Power Technology in British Industry, 1760-1870. PhD Thesis. University of Exeter.

King, P. (2005) 'The production and consumption of bar iron in early modern England and Wales.' Economic History Review 58(1) 1-33.

Kunnas, J. and T. Myllyntaus (2009) 'Postponed Leap in Carbon Dioxide Emissions: The Impact of Energy Efficiency, Fuel Choices and Industrial Structure on the Finnish Energy Economy, 1800-2005.' Global Environment 3.

Langdon, J. (1986) Horses, Oxen and Technological Innovation: the Use of Draught Animals in English Farming from 1066 to 1500. Cambridge University Press. Cambridge. 
Langdon, J. (2005) Mills in the Medieval Economy: England 1300-1540. Oxford University Press. Oxford.

Leach, G. (1992) ‘The energy transition.’ Energy Policy 20(2) 117-23.

Longo, A, A. Markandya and M. Petrucci (2008) 'The internalization of externalities in the production of electricity: Willingness to pay for the attributes of a policy for renewable energy.' Ecological Economics 67(1) 140-152.

Madureira, N.L. (2008) 'When the South emulates the North: energy policies and nationalism in the twentieth century.' Contemporary European History 17(1) 1-21.

Marcotullio, P. J. and N. B. Schulz (2007) 'Comparison of energy transitions in the United States and developing and industrializing economies.’ World Development 35(10) 1650-1683.

Pachauri, S. and L. Jiang (2008) 'The household energy transition in India and China.' Energy Policy 36(11) 4022-4035.

Pearce, D.W. (2005) 'Environmental policy as a tool for sustainability' in Simpson, R.D., M.A. Toman and R.U. Ayres (eds) Scarcity and Growth Revisited: Natural Resources and the Environment in the New Millennium. Resources for the Future. Washington D.C.

Pearson, P.J.G. (1988) Energy Transitions in Less-Developed Countries. Cambridge University Energy Research Group Discussion Paper. No.40. Cambridge.

Pollitt, M.G. (2010) UK Renewable Energy Policy since Privatisation. Cambridge Working Papers in Economics 1007, Faculty of Economics, University of Cambridge.

Schivelbusch, W. (1988) Disenchanted Night: The Industrialization of Light in the Nineteenth Century. Berg. Oxford.

Schurr, S. and Netschert, B. (1960) Energy in the American Economy, 1850 1975. John Hopkins Press. Baltimore, MD.

Smil, V. (1994) Energy in World History. Westview Press. Boulder, CO.

Smil, V. (2003) Energy at the Crossroads: Global Perspectives and Uncertainties. Cambridge, MA: The MIT Press.

van den Bergh, J. C. J. M. and F. H. Oosterhuis (2005) An Evolutionary Economic Analysis of Energy Transitions. ERSA conference papers. $45^{\text {th }}$ Congress of the European Regional Science Association.

Warde, P. (2007) Energy Consumption in England \& Wales 1560-2000. Napoli: Consiglio nazionale delle ricerche. 


\title{
BC3 WORKING PAPER SERIES
}

\author{
Basque Centre for Climate Change (BC3), Bilbao, Spain
}

The BC3 Working Paper Series is available on the internet at the following addresses:

http://www.bc3research.org/lits_publications.html

http://ideas.repec.org/s/bcc/wpaper.html

BC3 Working Papers available:

2009-01

Valentina Bosetti, Ruben Lubowski, Alexander Golub and Anil Markandya: Linking Reduced Deforestation and a Global Carbon Market: Impacts on Costs, Financial Flows, and Technological Innovation

Mikel González-Eguino: Market Instruments and CO2 Mitigation: A General Equilibrium Analysis for Spain

Aline Chiabai: Analysis and Use of Information and Communication Tools in Economics of Climate Change Ibon Galarraga, Mikel González-Eguino and Anil Markandya: The Role of Regions in Climate Change Policy

M.C. Gallastegui and Ibon Galarraga: Climate Change and Knowledge Communities

Ramon Arigoni Ortiz and Anil Markandya: Literature Review of Integrated Impact Assessment Models of Climate Change with Emphasis on Damage Functions

Agustin del Prado, Anita Shepherd, Lianhai Wu, Cairistiona Topp, Dominic Moran, Bert Tolkamp and David Chadwick: Modelling the Effect of Climate Change on Environmental Pollution Losses from Dairy Systems in the UK

Ibon Galarraga and Anil Markandya: Climate Change and Its Socioeconomic Importance

2009-09

Julia Martin-Ortega and Anil Markandya: The Costs of Drought: the Exceptional 2007-2008 Case of Barcelona

2009-11

Elena Ojea, Ranjan Ghosh, Bharat B. Agrawal and P. K. Joshi: The Costs of Ecosystem Adaptation: Methodology and Estimates for Indian Forests

Luis M. Abadie, José M. Chamorro, Mikel Gonzáez-Eguino: Optimal Investment in Energy Efficiency under Uncertainty

Sara L. M. Trærup, Ramon Arigoni Ortiz and Anil Markandya: The Health Impacts of Climate Change: A Study of Cholera in Tanzania

Mikel González-Eguino, Ibon Galarraga and Alberto Ansuategi: Carbon leakage and the Future of Old Industrial Regions after Copenhagen

Roger Fouquet: Divergences in the Long Run Trends in the Price of Energy and of Energy Services Application of Data Envelopment Analysis (DEA) 